\title{
Castor (Ricinus communis L.) Tolerance to Postemergence Herbicides and Weed Control Efficacy
}

\author{
W. James Grichar, ${ }^{1}$ Peter A. Dotray, ${ }^{2}$ and Calvin L. Trostle ${ }^{2}$ \\ ${ }^{1}$ Texas AgriLife Research, Beeville, TX 78102, USA \\ ${ }^{2}$ Texas AgriLife Extension Service, Lubbock, TX 79403, USA \\ Correspondence should be addressed to W. James Grichar, w-grichar@tamu.edu
}

Received 10 January 2012; Accepted 28 February 2012

Academic Editor: M. Tejada

Copyright ( 2012 W. James Grichar et al. This is an open access article distributed under the Creative Commons Attribution License, which permits unrestricted use, distribution, and reproduction in any medium, provided the original work is properly cited.

\begin{abstract}
Potential US castor production is limited due to only one labeled herbicide (trifluralin). Field studies were conducted at two Texas locations during 2008 and 2009 to evaluate postemergence herbicides for castor tolerance and weed control efficacy. Clethodim and fluazifop-P-butyl caused no castor stunting while acifluorfen, bentazon, imazethapyr, and lactofen caused stunting which ranged from 5 to $46 \%$. Imazapic and 2,4-DB caused the greatest stunting (44 to 99\%) and resulted in castor yields of 0 to $45 \%$ of the untreated check. Acifluorfen, imazapic, imazethapyr, lactofen, and 2,4-DB controlled at least 80\% smellmelon (Cucumis melo L. var. Dudaim Naud.) while clethodim and fluazifop-P-butyl controlled at least 98\% Texas millet [Urochloa texana (Buckl.) R.Webster]. Imazapic and imazethapyr provided 57 to $75 \%$ Texas millet control. Results suggest that castor tolerance to the graminicides, clethodim, and fluazifop-P-butyl is high; however, castor injury and yield reductions with the postemergence applications of broadleaf herbicides suggest that these herbicides should not be used in castor production.
\end{abstract}

\section{Introduction}

Castor is indigenous to the southeastern Mediterranean Basin, eastern Africa, and India, but is widespread throughout tropical regions and is widely grown elsewhere as an ornamental plant [1]. Thought to be native to tropical Africa, castor is a member of the Euphorbiaceae (spurge) family. Castor has been cultivated for centuries for the oil stored in its seeds. The seeds with hulls removed contain 35 to $55 \%$ oil. Leaves, stems, and particularly the seed of the plant contain ricin and ricinine, which are poisonous to humans and animals if ingested. However, ricin is not present in the oil.

Castor is grown on a limited basis (1,000 ha) in the United States. However, interest in US castor production has increased recently due to the introduction of the semidwarf variety "Brigham", which has 85 to $90 \%$ less ricin than the traditional US castor variety "Hale" [2]. Demand for castor peaked in the early 1950s when the US government increased supplies of castor oil for military applications in the event of a national emergency. US castor oil imports are used primarily for industrial and engineering applications including lubricants [3]. Heat treatment will denature ricin; thus castor meal (the residue left after the oil has been extracted from the seeds) may be used as a feed protein source for livestock. Castor pomace or meal has been included in mixed fertilizer.

Castor grows well in medium to sandy texture soils. It is best adapted to the semiarid to subtropical regions of the southern US [3]. The slow emergence (up to two weeks even with favorable conditions) [4] and slow initial growth of castor means the plants are not strong competitors with weeds. Rotary hoeing during the first few weeks after planting, followed by row cultivation, will provide favorable early-season weed control. Because the main lateral roots are near the soil surface, cultivation must be shallow. The authors could find a limited number of references that mentioned the evaluation of herbicides for weed control or castor tolerance to herbicides [3-7]. Selective postemergence (POST) herbicides are needed as limited preemergence (PRE) herbicides [4] are available to growers, and weed escapes will occur in castor production. The objective of 
this study was to identify selective POST herbicides for weed control and to evaluate castor tolerance to these herbicides.

\section{Materials and Methods}

2.1. Field Studies. Studies were conducted during the 2008 and 2009 growing seasons near Yoakum in south Texas and near Lubbock in the Texas High Plains to evaluate weed control and castor response to POST herbicides. Soil type near Yoakum was a Denhawken sandy loam (fine-silty, carbonitic, hyperthermic Fluventic Ustochrepts) with less than $1.0 \%$ organic matter and $\mathrm{pH}$ 7.6. Soil type at Lubbock was an Acuff sandy clay loam (fine-loamy, mixed, superactive thermic Aridic Paleustolls) with $<0.8 \%$ organic matter and pH 7.7.

A randomized complete-block experimental design was used, and herbicide treatments and rates were replicated three times. Plot size was two rows ( $97 \mathrm{~cm}$ apart) by $9.5 \mathrm{~m}$. at Yoakum and four rows (101 cm apart) by $7.3 \mathrm{~m}$. at Lubbock. At Lubbock only, the two middle rows per plot were sprayed, and the other rows were left untreated to serve as buffers. All POST herbicides at the Yoakum location included a crop oil concentrate (Agri-Dex, a blend of $83 \%$ paraffinbased petroleum oil and 17\% surfactant; Helena Chemical Company, Suite 500, 6075 Poplar Avenue, Memphis, TN 38137 , USA) at $2.3 \mathrm{~L} /$ ha while at the Lubbock location all POST herbicides included a nonionic surfactant (R-11, 90\% alkylphenol ethoxylate, butyl alcohol dimethylpolysiloxane; Wilbur-Ellis Company, P.O. Box 16458, Fresno, CA 93755, USA) at $0.25 \% \mathrm{v} / \mathrm{v}$. Herbicides were applied in water using a $\mathrm{CO}_{2}$-pressurized backpack sprayer with TeeJet 11002 DG (Spraying Systems Company, P.O. Box 7900, North Avenue, Wheaton, IL 60188, USA) nozzles calibrated to deliver $190 \mathrm{~L} / \mathrm{ha}$ at $180 \mathrm{kPa}$ at Yoakum and TurboTee 110015 nozzles calibrated to deliver $140 \mathrm{~L} / \mathrm{ha}$ at $207 \mathrm{kPa}$ at the Lubbock location. Herbicides included acifluorfen at $0.42 \mathrm{~kg}$ ai $/ \mathrm{ha}$, bentazon at $1.12 \mathrm{~kg}$ ai $/ \mathrm{ha}$, clethodim at $0.21 \mathrm{~kg}$ ai/ha, fluazifop-Pbutyl at $0.21 \mathrm{~kg}$ ai/ha, imazapic and imazethapyr at 0.03 and $0.07 \mathrm{~kg} \mathrm{ai} / \mathrm{ha}$, and lactofen at $0.05 \mathrm{~kg}$ ai $/ \mathrm{ha}$.

Natural infestations of smellmelon (Cucumis melon $\mathrm{L}$. var. Dudaim Naud.) and Texas millet [Urochloa texana (Buckl.) R. Webster] were present at the Yoakum location at the population rate of 6 to 10 plants $/ \mathrm{m}^{2}$ and 4 to 6 plants $/ \mathrm{m}^{2}$, respectively. Smellmelon was 20 to $46 \mathrm{~cm}$ in length, and Texas millet was 15 to $25 \mathrm{~cm}$ in height at the time of application. The untreated check at Yoakum was not maintained weed free; therefore, in these plots, weeds were allowed to grow freely. Postemergence herbicides were applied when castor was 30 to $40 \mathrm{~cm}$ in height at the Yoakum and 28 to $46 \mathrm{~cm}$ in height at Lubbock. At Lubbock, castor was planted in areas with low weed populations; therefore, plots were maintained "weed-free" for evaluating the herbicide effect on castor only. The untreated check at this location did not contain any herbicide treatment. The castor variety "Hale" $[3,4]$ was planted at both locations. Planting dates at the Yoakum location were March 27 in 2008 and May 11 in 2009 while at Lubbock, castor was planted May 22 in 2008 and May 28 in 2009. Castor seeds were planted approximately $4.0 \mathrm{~cm}$ deep with a density of $6 \mathrm{seed} / \mathrm{m}$ at both locations. Castor injury (stunting) due to POST herbicides was evaluated based on a scale of 0 (no stunting) to 100 (plant death).

The Yoakum site was rain-fed whereas at Lubbock the research site was furrow irrigated four times each season (approximately $254 \mathrm{~mm}$ per season). Rainfall was below normal for both 2008 and 2009 with above normal temperatures at the Yoakum and Lubbock locations [8].

When capsules were dry and the leaves had fallen from the plants, castor racemes were hand-cut, bagged, dried, and threshed with a stationary plot harvester (Almaco; Nevada, IA50201) to obtain yield. Castor yields were obtained at the Yoakum location in both years and in 2008 at Lubbock (stands too thin for reliable yield in 2009).

2.2. Statistical Analysis. Data for castor stunting and percentage of weed control were transformed to the arcsine square root prior to analysis; however, nontransformed means are presented because arcsine transformation did not affect the results of the data analysis. Data were subjected to ANOVA and analyzed using SAS PROC MIXED with locations and years designated as random effects in the model (SAS Institute Inc., Cary, NC, USA). Treatment means were separated using Fisher's Protected LSD at $P \leq 0.05$. The untreated check was used for yield comparisons and as a visual comparison for castor stunting and weed control. The untreated check was included in yield data analysis but not the weed efficacy or castor injury analysis.

\section{Results and Discussion}

Since there was no treatment by year interaction at Yoakum for castor stunting and yield or weed control, all data were combined over years. However, at Lubbock castor stunting data were not combined.

3.1. General Castor Injury/Stunting. Since Hale is a semidwarf variety [4], castor did not exceed $1.8 \mathrm{~m}$ in height. Leaf chlorosis and necrosis were evident with acifluorfen and lactofen while imazapic and imazethapyr resulted in reduced plant growth (stunting). Castor injury following 2,4DB treatments consisted of twisting and abnormal growth typical of hormonal injury along with stunting. Only stunting is being reported in this paper.

3.2. Castor Stunting in South Texas. When evaluated $17 \mathrm{~d}$ after treatment (DAT), all herbicides with the exception of clethodim and fluazifop-P-butyl resulted in castor stunting (Table 1). Both rates of 2,4-DB resulted in the greatest stunting $(>88 \%)$ while lactofen resulted in $25 \%$ stunting. When evaluated 40 DAT, 2,4-DB resulted in at least 78\% stunting while imazapic caused 57 to $74 \%$ stunting. Acifluorfeninduced stunting was $29 \%$, but none of the other herbicides caused stunting that was greater than clethodim or fluazifopP-butyl.

3.3. Castor Stunting in the Texas High Plains. When rated 21 DAT in 2008, 2,4-DB caused greater than $90 \%$ stunting while 
TABLE 1: Castor response and weed control to postemergence herbicides in south Texas, 2008-2009.

\begin{tabular}{lcccccc}
\hline \multirow{2}{*}{ Treatment, } & \multicolumn{3}{c}{ Stunting } & \multicolumn{3}{c}{ Control } \\
& Dose (Kg ai/ha) & 17 DAT & 40 DAT & $\begin{array}{c}\text { Cucumis melo } \\
\text { Urochloa texana }\end{array}$ & Yield (Kg/ha) \\
\hline Untreated & - & 0 & 0 & 0 & 0 & 349 \\
Acifluorfen & 0.42 & 35 & 29 & 82 & 0 & 375 \\
Bentazon & 1.12 & 34 & 10 & 45 & 0 & 162 \\
Clethodim & 0.21 & 0 & 0 & 0 & 98 & 673 \\
Fluazifop-P-butyl & 0.21 & 0 & 0 & 0 & 100 & 663 \\
Imazapic & 0.03 & 44 & 57 & 93 & 65 & 26 \\
Imazapic & 0.07 & 60 & 74 & 99 & 73 & 0 \\
Imazethapyr & 0.03 & 46 & 22 & 80 & 75 & 205 \\
Imazethapyr & 0.07 & 38 & 15 & 94 & 57 & 149 \\
Lactofen & 0.05 & 25 & 5 & 92 & 0 & 82 \\
2,4-DB & 0.25 & 88 & 78 & 86 & 0 & 0 \\
2,4-DB & 0.46 & 96 & 99 & 82 & 33 & 306 \\
LSD (0.05) & & 20 & 25 & 19 & & 0 \\
\hline
\end{tabular}

${ }^{a}$ Untreated was not maintained weed free and contained all the weeds found in the test area.

${ }^{\mathrm{b}}$ Agridex added to all treatments at $0.25 \% \mathrm{v} / \mathrm{v}$.

'Abbreviations: DAT: days after POST application.

stunting with imazapic ranged from 68 to $75 \%$ (Table 2). Acifluorfen, bentazon, both rates of imazethapyr, and lactofen caused castor stunting which ranged from 12 to $25 \%$. When rated 42 DAT, 2,4-DB and imazapic still caused the greatest stunting while acifluorfen, imazethapyr at $0.07 \mathrm{~kg} / \mathrm{ha}$, and lactofen caused 10 to $15 \%$ castor stunting relative to the untreated check. No stunting was noted following either clethodim or fluazifop-P-butyl.

In 2009, 2,4-DB-induced stunting of castor was greater than $90 \%$ whereas stunting from imazapic ranged from 78 to $83 \%$ and stunting from imazethapyr was at least $25 \%$ at 28 DAT (Table 2). At 42 DAT, castor stunting from imazapic and $2,4-\mathrm{DB}$ was at least $79 \%$. Castor stunting from bentazon and from the high rate of imazethapyr ranged from 17 to $30 \%$, while stunting from acifluorfen, clethodim, and fluazifop-Pbutyl, the low rate of imazethapyr was $10 \%$ or less, and, as in 2008 , there was no stunting from clethodim or fluazifop-Pbutyl relative to the untreated check.

Castor appears to be more subject to imazapic injury than peanut. Several studies have reported stunting in peanut similar to castor after imazapic application [9-12]; however, Jordan et al. [11] reported that imazapic alone resulted in peanut stunting which was no greater than $20 \%$ when evaluated 2 wks after treatment, but little or no injury was noted $5 \mathrm{wk}$ after herbicide application. In contrast to castor, Grichar et al. [13] also reported little or no injury on peanut with imazapic when applied to peanut in south Texas.

3.4. Broadleaf Weed Control. All herbicides that are considered broadleaf inhibitors, with the exception of bentazon, controlled at least $80 \%$ smellmelon in south Texas (Table 1). Imazethapyr and imazapic are imidazolinone herbicides registered for use in peanut (Arachis hypogaea L.). Imazethapyr may be applied preplant incorporated (PPI), PRE, ground cracking, or POST for effective weed control [14]. Imazethapyr applied PPI or PRE controls many troublesome weeds such as coffee senna (Cassia occidentalis L.), common lambsquarter (Chenopodium album L.), morningglory species (Ipomoea spp.), pigweed species (Amaranthus spp.) including Palmer amaranth (Amaranthus palmeri S. Wats), prickly sida (Sida spinosa L.), purple and yellow nutsedge (Cyperus rotundus L. and C. esculentus L., resp.), spurred anoda [Anoda cristata (L.) Schlecht.], and wild poinsettia (Euphorbia heterophylla L.) [15-17].

Imazethapyr applied POST provides broad spectrum and most consistent control when applied within $10 \mathrm{~d}$ of weed emergence $[16,18,19]$. Imazethapyr and imazapic are the only POST herbicides to effectively control both yellow and purple nutsedge $[17,20]$. Control is most effective when imazethapyr is applied to the soil or to yellow nutsedge that is no more than $13 \mathrm{~cm}$ in height $[14,20,21]$.

Bentazon increases control of paraquat-tolerant species such as bristly starbur (Acanthospermum hispidum DC.), coffee senna, prickly sida (Sida spinosa L.), and smallflower morningglory [Jacquemontia tamnifolia (L.) Griseb.] and reduces paraquat-induced injury to peanut [22]. Lactofen is classified as a diphenyl ether (cell membrane disruptor), which interferes with protoporphyrinogen IX oxidase and causes accumulation of protoporphyrin IX [23]. Protoporphyrinogen IX is a potent photosensitizer that generates high levels of singlet oxygen in the presence of molecular oxygen and light, leading to light-induced oxidative breakdown of cell constituents [23]. In general, foliar herbicides classified as cell membrane disruptors must be applied to small weeds. Similar to the results seen with castor, peanut, and 
TABle 2: Castor response to postemergence herbicides in the High Plains of Texas under weed-free conditions.

\begin{tabular}{|c|c|c|c|c|c|c|}
\hline \multirow{4}{*}{ Treatment ${ }^{\mathrm{a}, \mathrm{b}}$} & \multirow{4}{*}{ Dose (Kg ai/ha) } & \multicolumn{4}{|c|}{ Stunting } & \multirow{4}{*}{$\begin{array}{c}2008 \\
\text { Yield (Kg/ha) }\end{array}$} \\
\hline & & \multicolumn{2}{|c|}{2008} & \multicolumn{2}{|c|}{2009} & \\
\hline & & $21 \mathrm{DAT}^{\mathrm{c}}$ & $42 \mathrm{DAT}$ & $28 \mathrm{DAT}$ & 42 DAT & \\
\hline & & \multicolumn{4}{|c|}{$\%$} & \\
\hline Untreated & - & 0 & 0 & 0 & 0 & 1532 \\
\hline Acifluorfen & 0.42 & 15 & 13 & 27 & 5 & 1479 \\
\hline Bentazon & 1.12 & 18 & 5 & 27 & 17 & 1237 \\
\hline Clethodim & 0.21 & 0 & 0 & 2 & 0 & 1311 \\
\hline Fluazifop-P-butyl & 0.21 & 0 & 0 & 5 & 0 & 1240 \\
\hline Imazapic & 0.03 & 68 & 50 & 78 & 79 & 691 \\
\hline Imazapic & 0.07 & 75 & 65 & 83 & 90 & 375 \\
\hline Imazethapyr & 0.03 & 12 & 5 & 25 & 10 & 1191 \\
\hline Imazethapyr & 0.07 & 25 & 15 & 42 & 30 & 1232 \\
\hline Lactofen & 0.05 & 17 & 10 & 18 & 7 & 1403 \\
\hline $2,4-\mathrm{DB}$ & 0.25 & 91 & 87 & 97 & 94 & 0 \\
\hline $2,4-\mathrm{DB}$ & 0.46 & 97 & 95 & 94 & 88 & 0 \\
\hline LSD (0.05) & & 6 & 7 & 11 & 12 & 281 \\
\hline
\end{tabular}

${ }^{\mathrm{a}}$ Untreated was maintained weed free.

${ }^{\mathrm{b}} \mathrm{R}-11$ surfactant added to all treatments at $0.25 \% \mathrm{v} / \mathrm{v}$.

${ }^{\mathrm{c}}$ Abbreviations: DAT: days after treatment.

soybean (Glycine max L.) tolerance to lactofen is based on metabolism, which often results in some leaf bronzing and spotting of leaves, and plant growth is often temporarily reduced [24].

3.5. Annual Grass Control. Texas millet control with clethodim and fluazifop-P-butyl was at least 98\% while imazapic and imazethapyr controlled Texas millet no better than $75 \%$ (Table 1). Postemergence control of annual grasses may be obtained with either clethodim or fluazifop-P-butyl [25]. Grichar et al. [26] reported that fluazifop-P-butyl and sethoxydim increased sesame (Sesamum indicum L.) yield over the untreated check, and this was attributed to the control of Texas millet and southern crabgrass. Imazapic will control Texas millet when applied to plants less than $2.5 \mathrm{~cm}$ in height, while imazethapyr alone provides inconsistent control even when applied to small Texas millet [13].

3.6. Castor Yield in South Texas. Low yield from both years may be attributed to extremely dry conditions and high weed populations during both growing seasons. Clethodimand fluazifop-P-butyl-treated plots produced the greatest yield ( $\geq 663 \mathrm{~kg} / \mathrm{ha}$ ) while imazapic and 2,4-DB-treated plots produced little or no castor yield (Table 1). Competition from weeds can severely reduce yield of many crops [9, $12,13,25]$. Knake and Slife [27] reported that the greatest competitive effect of weeds on soybean appeared to occur after the start of the reproductive stage while Dalley et al. [28] reported that weeds reaching $30 \mathrm{~cm}$ in height in widerow soybean did not reduce yield. Similar to the results seen with castor, annual grasses and broadleaf weeds can influence peanut yields as well [29-31]. Not only does the competition from these weeds reduce peanut yield, but their extensive root system interferes with harvesting efficiency [32].

3.7. Castor Yield in the Texas High Plains. Castor yields were much higher than those from the south Texas location due to three furrow irrigations applied during the growing season. Castor yields from acifluorfen-, clethodim-, or lactofentreated plots were not different than the untreated check (Table 2). Due to the severe castor stunting, 2,4-DB treated plots produced no yields while those from the imazapictreated plots yielded 24 to $45 \%$ of the untreated check. Bentazon, fluazifop-P-butyl, and imazethapyr reduced yields 19 to $22 \%$ when compared with the untreated check.

Sustained castor injury levels and yield reductions due to bentazon, imazapic, imazethapyr, and 2,4-DB may merit possible postemergence testing with directed sprays or hooded sprayers in contrast to the over-the-top applications tested in this trial (authors' personal opinion).

\section{Conclusions}

The use of a POST herbicide in castor to remove broadleaf weeds appears to be limited due to lack of castor tolerance. All herbicides considered broadleaf inhibitors provided at least $80 \%$ smellmelon control but caused early-season castor stunting that resulted in yields that were no better than the untreated check which was not maintained weed free. The graminicides, clethodim, and fluazifop-P-butyl provided excellent (at least 98\%) control of the annual grass, Texas millet, with no castor stunting. Plots that showed a lack of annual grass pressure due to weed control and no castor stunting resulted in the greatest yields. 


\section{Acknowledgment}

This project was funded by the Texas Department of Agriculture.

\section{References}

[1] R. Phillips and M. Rix, Annuals and Biennials, Macmillan, London, UK, 1999.

[2] D. L. Rowland, J. M. Rieff, and J. S. Oswalt, "Castor (Ricinus communis L.) oil production in Texas," in Proceedings of the The 19th International Symposium on Plant Lipids, p. 40, Cairns, Australia, July 2010.

[3] R. D. Brigham, "Castor: return of an old crop," in New Crops, J. Janick and J. E. Simon, Eds., pp. 380-383, Wiley Publishing, New York, NY, USA, 1993.

[4] C. Trostle, S. Wallace, and D. Auld, "Keys and concerns for castor production in Texas: the 'first things' you need to know," Department of Soil and Crop Science, SCS-2012-37, Texas A\&M University, College Station, Tex, 2012.

[5] V. A. Moshkin, Castor, Amerind Publishing, New Delhi, India, 1986.

[6] J. F. Peacock, O. C. Burnside, T. L. Lavy, D. G. Hanway, and D. L. Kittock, "Flaming, intertillage, and chemical weed control in castorbeans," Weeds, vol. 13, no. 4, pp. 290-292, 1965.

[7] H. M. El-Saht, M. N. A. Hasaneen, and F. M. Bassyoni, "Effects of metribuzin herbicide on nitrogen, pigments, protease and nitrate reductase activity of normal and $\mathrm{NaCl}$-stressed castor bean and maize plants," Biologia Plantarum, vol. 36, no. 2, pp. 267-275, 1994.

[8] National Climatic Data Center, http://www.ncdc.noaa.gov/oa/ ncdc.html.

[9] J. S. Richburg III, J. W. Wilcut, D. L. Colvin, and G. R. Wiley, "Weed management in southeastern peanut (Arachis hypogaea) with AC 263,222," Weed Technology, vol. 10, no. 1, pp. 145-152, 1996.

[10] J. S. Richburg III, J. W. Wilcut, A. K. Culbreath, and C. K. Kvien, "Response of eight peanut (Arachis hypogaea) cultivars to the herbicide AC 263,222," Peanut Science, vol. 22, pp. 7680, 1995.

[11] D. L. Jordan, J. F. Spears, and J. W. Wilcut, "Tolerance of peanut (Arachis hypogaea L.) to herbicides applied postemergence," Peanut Science, vol. 3, pp. 8-13, 2003.

[12] G. Wehtje, D. Padgett, and N. R. Martin Jr., "Imazapic-based herbicide systems for peanut and factors affecting activity on Florida beggarweed," Peanut Science, vol. 27, no. 1, pp. 17-22, 2000.

[13] W. J. Grichar, B. A. Besler, R. G. Lemon, and K. D. Brewer, "Weed management and net returns using soil-applied and postemergence herbicide programs in peanut (Arachis hypogaea L.)," Peanut Science, vol. 32, pp. 25-31, 2005.

[14] J. W. Wilcut, A. C. York, W. J. Grichar, and G. R. Wehtje, "The biology and management of weeds in peanut (Arachis hypogaea)," in Advances in Peanut Science, H. E. Pattee and H. T. Stalker, Eds., pp. 207-244, American Peanut Research Education Society, Stillwater, Okla, USA, 1995.

[15] T. A. Cole, G. R. Wehtje, J. W. Wilcut, and T. V. Hicks, "Behavior of imazethapyr in soybeans (Glycine max), peanuts (Arachis hypogaea), and selected weeds," Weed Science, vol. 37, no. 5, pp. 639-644, 1989.

[16] J. W. Wilcut, F. R. Walls Jr., and D. N. Norton, "Imazethapyr for broadleaf weed control in peanuts (Arachis hypogaea)," Peanut Science, vol. 18, no. 1, pp. 26-30, 1991.
[17] W. J. Grichar, P. R. Nester, and A. E. Colburn, "Nutsedge (Cyperus spp.) control in peanuts (Arachis hypogaea) with imazethapyr," Weed Technology, vol. 6, no. 2, pp. 369-400, 1992.

[18] J. W. Wilcut, J. S. Richburg III, E. F. Eastin, G. R. Wiley, F. R. Walls Jr., and S. Newell, "Imazethapyr and paraquat systems for weed management in peanut (Arachis hypogaea)," Weed Science, vol. 42, no. 4, pp. 601-607, 1994.

[19] J. W. Wilcut, J. S. Richburg III, G. Wiley, F. R. Walls Jr., S. R. Jones, and M. J. Iverson, "Imidazolinone herbicide systems for peanut (Arachis hypogaea)," Peanut Science, vol. 21, no. 1, pp. 23-28, 1994.

[20] J. S. Richburg III, J. W. Wilcut, and G. R. Wehtje, "Toxicity of foliar and/or soils applied AC 263,222 to purple (Cyperus rotundus) and yellow nutsedge (C. esculentus)," Weed Science, vol. 42, no. 3, pp. 398-402, 1993.

[21] J. W. Wilcut, A. C. York, and G. R. Wehtje, "The control and interaction of weeds in peanut (Arachis hypogaea)," Review of Weed Science, vol. 6, pp. 177-205, 1994.

[22] G. Wehtje, J. W. Wilcut, and J. A. McGuire, "Influence of bentazon on the phytotoxicity of paraquat to peanuts and associated weeds," Weed Science, vol. 40, no. 1, pp. 90-95, 1992.

[23] S. O. Duke, J. Lydon, J. M. Becerril, T. D. Sherman, L. P. Lehnen Jr., and H. Matsumoto, "Protoporphyrinogen oxidaseinhibiting herbicides," Weed Science, vol. 39, no. 3, pp. 465$473,1991$.

[24] J. R. Harris, B. J. Gossett, T. R. Murphy, and J. E. Toler, "Response of broadleaf weeds and soybeans to the diphenyl ether herbicides," Journal Production Agriculture, vol. 4, pp. 407-411, 1991.

[25] W. J. Grichar, "Control of Texas panicum (Panicum texanum) and southern crabgrass (Digitaria ciliaris) in peanuts (Arachis hypogaea) with postemergence herbicides," Peanut Science, vol. 18 , no. 1, pp. 6-9, 1991.

[26] W. J. Grichar, D. C. Sestak, K. D. Brewer, B. A. Besler, C. R. Stichler, and D. T. Smith, "Sesame (Sesamum indicum L.) tolerance with various postemergence herbicides," Crop Protection, vol. 20, no. 8, pp. 685-689, 2001.

[27] E. L. Knake and F. W. Slife, "Effect of time of giant foxtail removal from corn and soybeans," Weed Science, vol. 17, no. 3, pp. 281-283, 1969.

[28] C. D. Dalley, J. J. Kells, and K. A. Renner, "Effect of glyphosate application timing and row spacing on corn (Zea mays) and soybean (Glycine max) yields," Weed Technology, vol. 18, no. 1, pp. 165-176, 2004.

[29] B. J. Brecke and D. L. Colvin, "Weed management in peanuts," in CRC Handbook of Pest Management in Agriculture, D. Pimentel, Ed., vol. 3, pp. 239-251, CRC Press, Boca Raton, Fla, USA, 1991.

[30] W. J. Grichar, "Spiny amaranth (Amaranthus spinosus L.) control in peanut (Arachis hypogaea L.)," Weed Technology, vol. 8, no. 2, pp. 199-202, 1994.

[31] J. W. Wilcut, G. R. Wehtje, and R. H. Walker, "Economics of weed control in peanuts (Arachis hypogaea) with herbicides and cultivations," Weed Science, vol. 35, no. 5, pp. 711-715, 1987.

[32] G. A. Buchanan, D. S. Murray, and E. W. Hauser, "Weeds and their control in peanuts," in Peanut Science and Technology, $\mathrm{H}$. E. Pattee and C. T. Young, Eds., pp. 209-249, American Peanut Research Education Society, Yoakum, Tex, USA, 1982. 


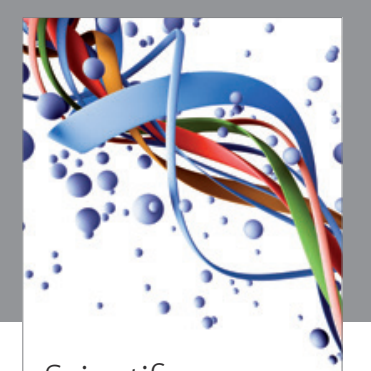

Scientifica
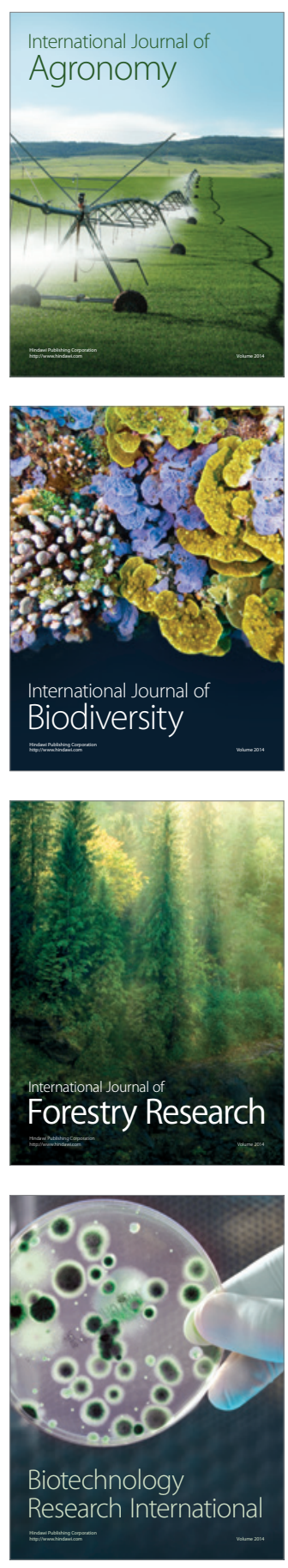
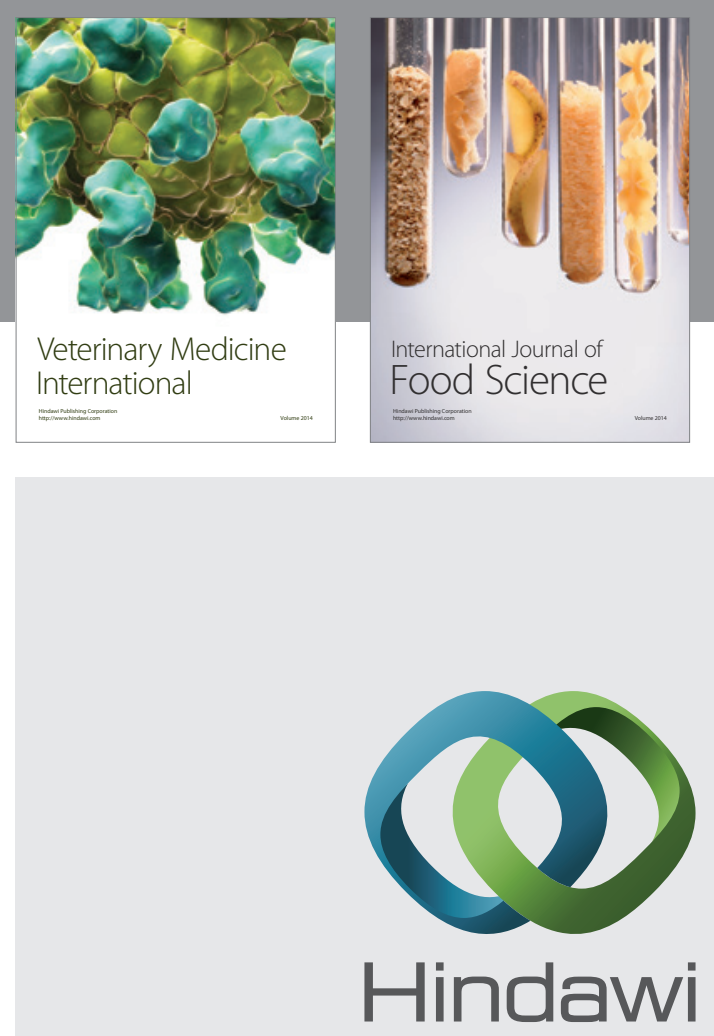

Submit your manuscripts at

http://www.hindawi.com
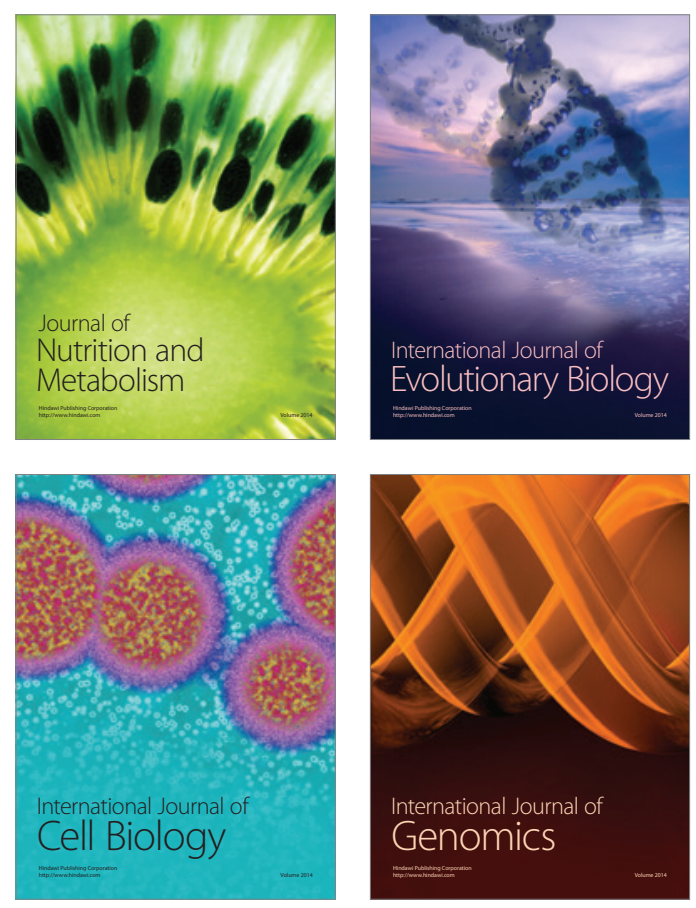
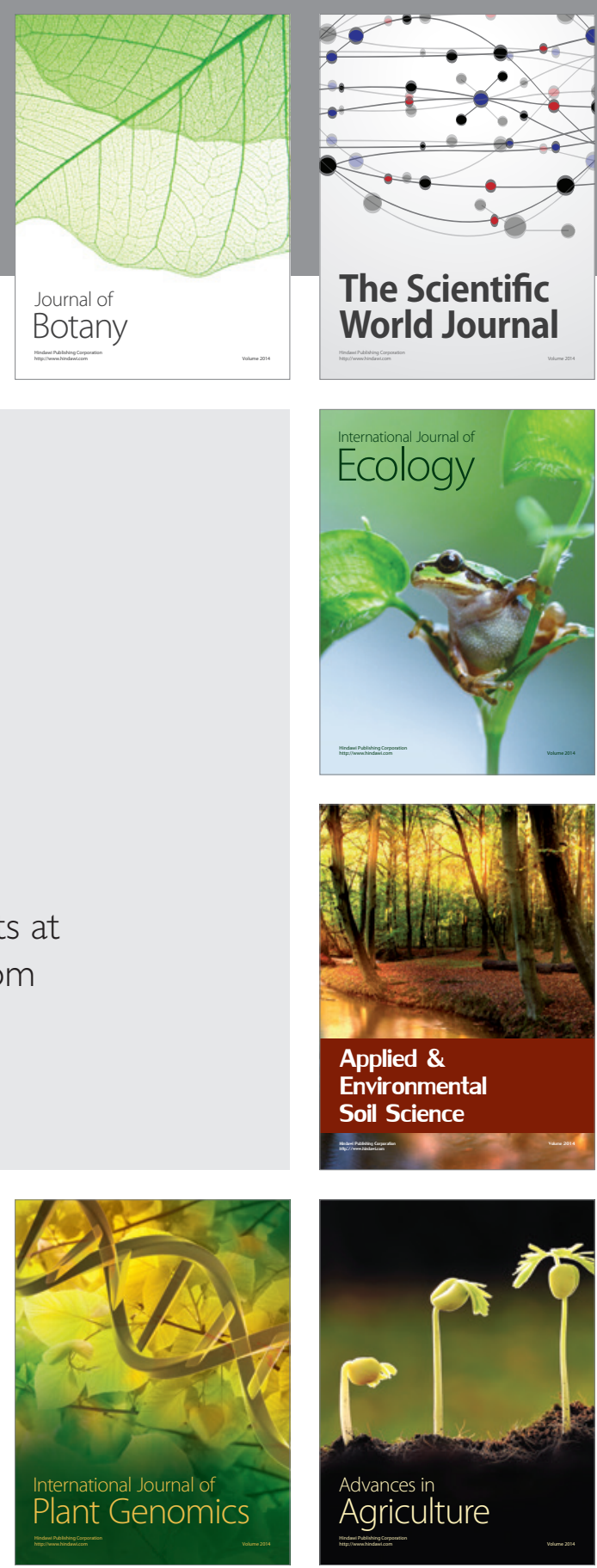

The Scientific World Journal
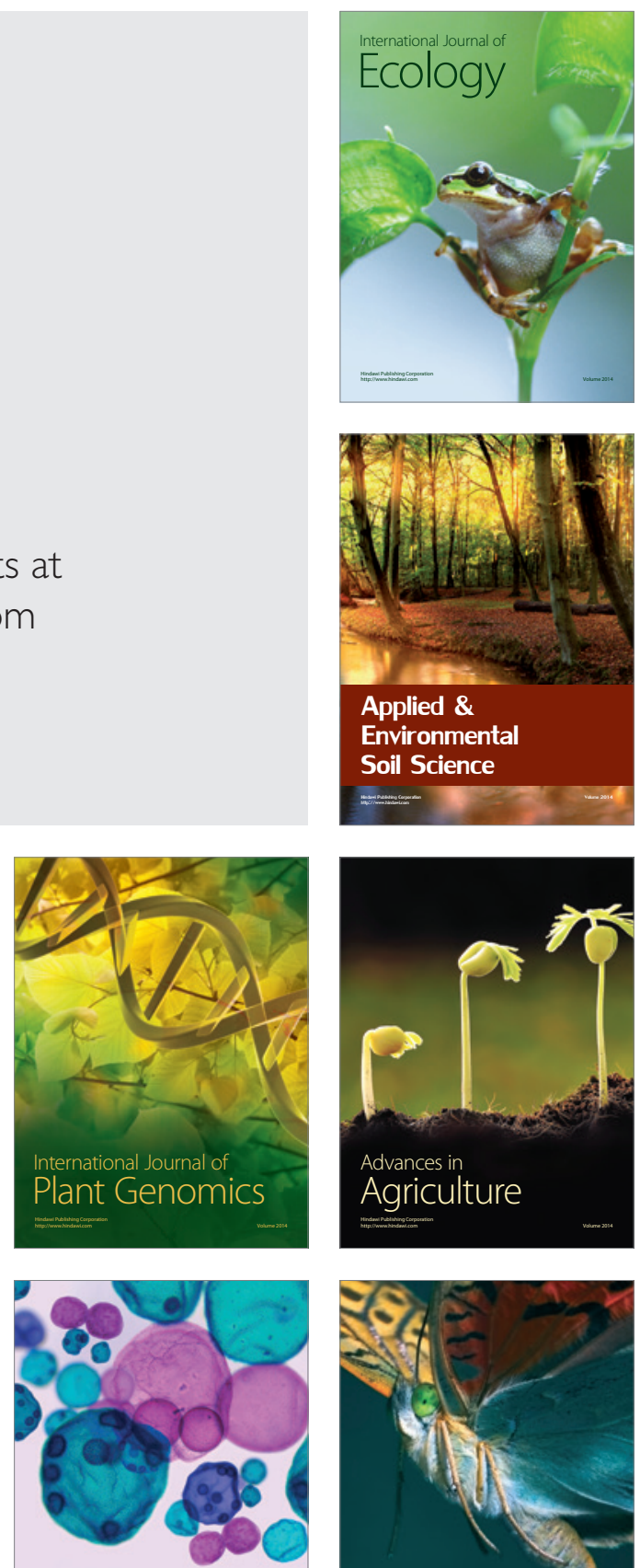

International Journal of Microbiology

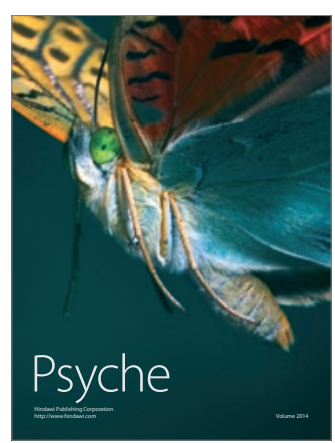

